Received 29.03.2017 Reviewed 27.04.2017 Accepted 04.05.2017

A - study design

B - data collection

C - statistical analysis

D - data interpretation

$\mathbf{E}$ - manuscript preparation

F- literature search

\section{Application of green blue roof to mitigate heat island phenomena and resilient to climate change in urban areas: A case study from Seoul, Korea}

\author{
Muhammad SHAFIQUE ${ }^{1) B C D F} \bowtie$, Reeho KIM ${ }^{1), 2) ~ A E}$
}

\footnotetext{
${ }^{1)}$ Department of Construction Environment Engineering, Korea Institute of Civil Engineering and Building Technology Campus, University of Science and Technology, 283, Goyangdae-Ro, Ilsanseo-Gu, Goyang-Si, Geonggi-Do, Republic of Korea; e-mail: shafique@ust.ac.kr

2) Environmental and Plant Engineering Research Institute, Korea Institute of Civil Engineering and Building Technology, 283, Goyangdae-Ro, Ilsanseo-Gu, Goyang-Si, Gyeonggi-Do, 10223, Republic of Korea; e-mail: rhkim@kict.re.kr
}

For citation: Shafique M., Kim R. 2017. Application of green blue roof to mitigate heat island phenomena and resilient to climate change in urban areas: A case study from Seoul, Korea. Journal of Water and Land Development. No. 33 p. 165-170. DOI: 10.1515/jwld-2017-0032.

\begin{abstract}
Green blue roof has the potential to reduce the surface temperature of the building in the urban areas. Green blue roof is a new innovative low impact development (LID) practice that has exhibited an option to mitigate the heat island phenomena in urban area. This is the modified form of green roof that has ability to store rainwater in vegetation, soil layer and increases the evapotranspiration rate which decreases the temperature of an area. For this purpose, green blue roof is installed at the Cheong-un middle school building roof, Seoul, Korea. During the different time scenarios the surface temperature from the green blue roof and control roof were analyzed and their results were compared with each other. The results revealed that the surface temperature of green blue roof was much less as compared to control roof under same climatic conditions. From the results it is also concluded that surface temperature value of green blue roof was less than $5^{\circ} \mathrm{C}$ to $9^{\circ} \mathrm{C}$ as compared to control roof.
\end{abstract}

Key words: green blue roof, low impact development (LID), temperature reduction, urban area, urban heat island (UHI)

\section{INTRODUCTION}

Urban area temperature is higher than the rural area temperature, this phenomenon is known as 'urban heat island' (UHI). UHIs have been studied for decades [ADINNA et al. 2009; NIACHOU et al. 2001; NURUZZAMAN 2015]. An urban heat island phenomenon is the result of urbanization and causes many adverse effects on an area. UHI has many undesirable environmental and economic impacts, i.e. degradation of the natural environment [AKBARI, KONOPACKI 2004; GRIMMOND 2007] increase the energy consumption of an area [AKBARI, KONOPACKI 2005] and increase in the loss of life [NURUZZAMAN MD. 2015].
Furthermore, to fulfil the demand in an area, more generation of power is needed, which results boosted the amount of greenhouse gases emission and decline of the natural environment. One of the significant reasons for the formation of UHI is the large amount of impervious surfaces (asphalt, concrete) i.e. roads, building and roof have a capacity to absorb the high heat [AKBARI et al. 2001]. Therefore, there is need to develop a new innovative approach that can mitigate the adverse effects of the urban heat island phenomena. Many studies have indicated the correlation between an increase in green areas and a reduction in local temperature [TAKEBAYASHI, MORIYAMA 2007], 
suggesting the implementation of the vegetation as a possible mitigation strategy for the UHI.

In urban areas roof areas are accounted approximately $50 \%$ of the total area [STOVIN et al. 2012]. This large amount of area if convert into green roofs can give many benefits in an urban area, including stormwater management [HOSSAIN, BAHAUDDIN 2013; SHAFIQUE et al. 2016; SURMA 2015], control heat waves [FENG et al. 2013; SANTAMOURIS 2014], increase biodiversity, improve the air quality of an area [LUO 2009], increase life span of the building, reduction in noise, and energy consumption costs [LUO 2009; SAIZ et al. 2016; XIAO et al. 2014]. Green roofs are sustainable stormwater management approach in the urban areas [SHAFIQUE et al. 2016]. Green roof increases the evapotranspiration rate and decreases heat island phenomena and reduces the energy consumption costs [SAIZ et al. 2016]. TANG et al. [2007] applied green roof at Chongqing, China to check the performance of green roof for temperature reduction. He proposed that the reduction in the inner surface temperature best reflects the thermal impact of the green roof on preventing the solar radiation from reaching the roof surface directly. From his experiments, it is proved that green roof has the ability to reduce inner roof surface temperature almost $1.8^{\circ} \mathrm{C}$ on an average as compared to normal roof. YIN and LI [2007] installed the green roof at Beijing, China. Results showed the green roof reduced outside roof surface temperature $2.4^{\circ} \mathrm{C}$ on average as compared to normal roof. ODLI et al. [2016] study results also showed the green roof reduced the indoor average temperature $2.4^{\circ} \mathrm{C}$. Different researchers [ARABI et al. 2015; LI et al. 2014; SHARMA et al. 2016; SHISHEGAR 2014] from all around the world studied green roof for the temperature reduction within an area. SHARMA et al. [2016] used the regional climatic model at Chicago, USA to evaluate the green roof performance to control the heat island phenomena. Results indicate that the green roof reduced $1{ }^{\circ} \mathrm{C}$ to $3^{\circ} \mathrm{C}$ of temperate during the peak hours.

Green roof is the best management practices to reduce the heat island phenomena in urban areas [PENG, JIM 2013]. For this purpose, green blue roof was installed at Cheong-un middle school building roof, Seoul, Korea. This is a new modified form of green roof with an additional storage layer that can store more rainwater. In the small scale approach, we have monitored the surface temperature from the green blue roof and control roof during the different time period and compared their results. Moreover, we have analyzed the results and evaluated the performance of green blue roof to control the heat island phenomena.

\section{UHI PHENOMENA AND IT NEGEATIVE EFFECTS ON URBAN AREAS}

Urban heat island (UHI) in a city is the significantly rising of temperature as compared to its surrounding rural areas due to human activities [NURUZZAMAN 2015]. The difference in temperature is usually more at night than the day. The main causes of the urban heat island are the land modification in urban areas [ADINNA et al. 2009; NURUZZAMAN 2015]. There are several causes of urban heat island, for example dark surfaces of roads and buildings absorb more heat as compared to the surrounding rural area [NURUZZAMAN 2015]. In urban areas, pavement and roofs are usually made of concrete and asphalt. These surfaces absorbed more solar radiations, change the energy budget of urban area and also raising the temperature than the surrounding rural areas [ADINNA et al. 2009; NURUZZAMAN 2015]. Due to lack of vegetation in urban areas, the evapotranspiration rate is low which also the reason of raising the temperature of urban area [SANTOS 2013]. Figure 1 shows the adverse effect of the heat island phenomena in highly developed urban areas.

As a result of this, the natural environment is degrading and cities are suffering with many problems such as increase the mortality rate and greenhouse gases (GHG) emission and energy costs. So there is a need to develop a new sustainable approach that can mitigate all these adverse effect and can make our cities safer, sustainable and resilient to climate change.

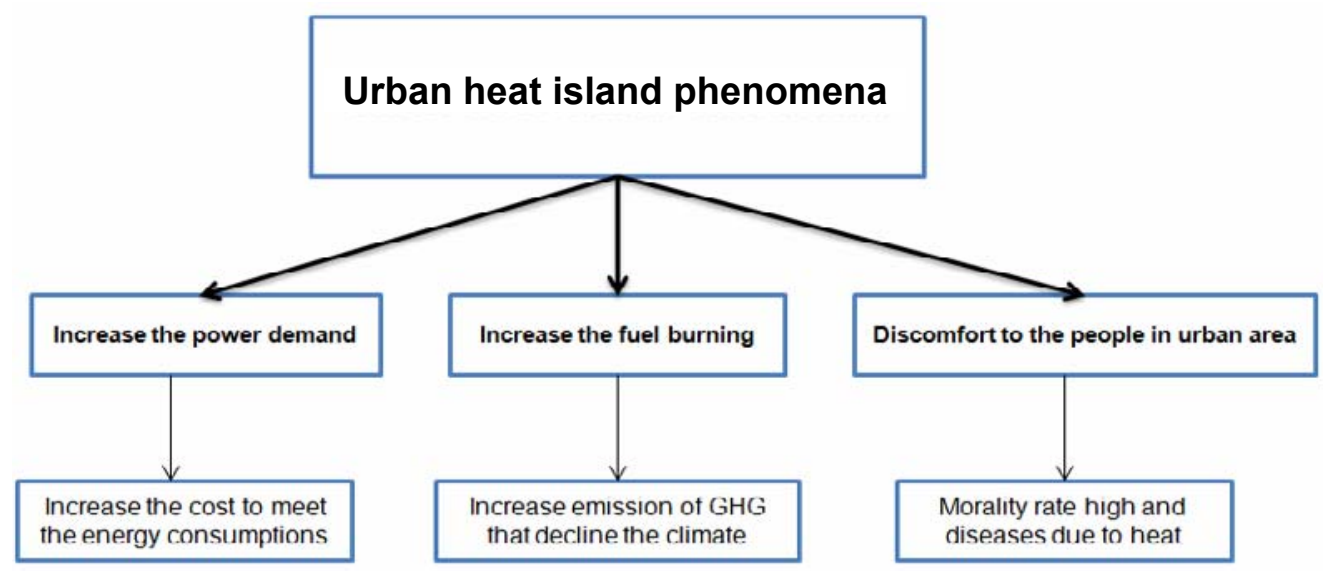

Fig. 1. Effect of the urban heat island phenomena in urban areas; source: own elaboration 


\section{MATERIAL AND METHOD}

\section{GREEN BLUE ROOF SITE AND WORKING MECHNISM}

The green blue roof is a combination of two words: green and blue where the green means the roof has vegetation/plants and blue means the roof has storage layer same as blue roof. This new modified concept of green roofs is developed by the Korea institute of Civil Engineering and Building Technology (KICT) researchers to achieve the multiple benefits. The main advantage of this roof is that this roof can store more water through different layers and also helpful to control the heat island phenomena.

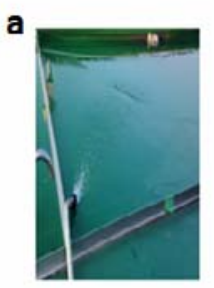

Blue roof: used weirs to detain the storm water management

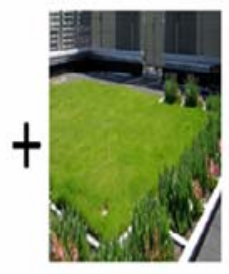

Green roof: used soil with vegetation layers for the storm wanagement
manate

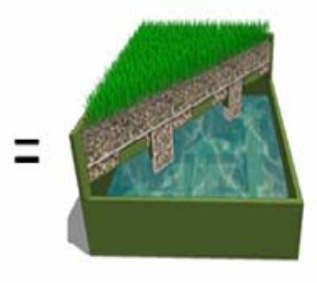

Green blue roof: new modified form of green roof that uses soil layer with vegetation, and additional storage layer for storing more water and to achiev to multiple benefits

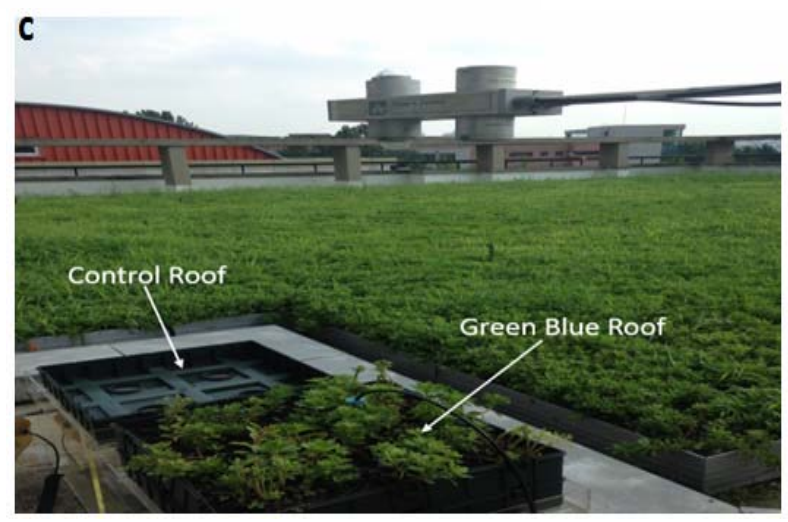

The green blue roof is a new low impact development (LID) technology that has a same concept as green roof difference that this roof type has one more storage layer. This roof showed the numerous benefits in an urban area. These roofs have plants/vegetation, soil layer, the filter layer, storage layer and drainage layer. The main purpose of the roof is to control the rainfall runoff and improve the natural environment of an urban area. The water is collected into soil media as well as in the extra storage layers which reduce the flash flooding in urban areas. The green blue roof enhances the evapotranspiration rate, which decreases the temperature of the surrounding area. Figure 2 represents the detailed green blue roof explanation.
This roof was constructed at the Cheong-un middle school building, Seoul, Korea. This site is located in the highly developed urban area of the Seoul, Republic of Korea. This roof structure was made of special plastic material and it is laid at the building rooftop. Several assemblies of $0.5 \times 0.5 \times 0.2 \mathrm{~m}$ are connected in this roof system. The total catchment area covered by these plastic assemblies is $285 \mathrm{~m}^{2}$. The green blue roof consists of several layers which have their own functions.

The study site includes the weather station, which records temperature, wind speed, relative humidity, and rainfall data. Figure $2 \mathrm{c}$ indicated the control roof and green blue roof specimens which were used to measure the surface temperature during the different time period. The data of the different time periods in August, September 2014 and April, May 2015 were collected and analyzed from the green blue roof and control roof to measure the surface temperature. The results are compared to show the surface temperature
Fig. 2. Green blue roof detailed explanation: a) green blue roof concept, b) layers of green blue roof, c) green blue roof site at Cheong-un middle school roof Seoul, Korea; source: own elaboration

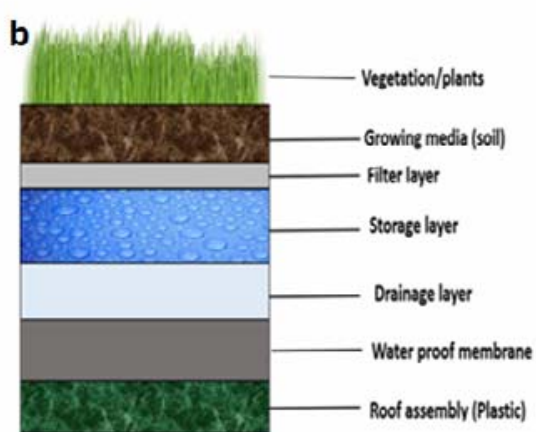

difference from the both roofs. The main purpose of this research is to show the how the green blue roof practice is effective to reduce the surface temperature and urban control heat island phenomena in urban areas.

\section{OVERVIEW OF INSTRUMENT USED FOR SURFACE TEMPRATURE MEANSUREMENT}

The instrument used for the surface temperature measurement was platinum silicone patch sensors (RTF5) as shown in Figure 3. This is sensor type is Pt100, a thin film class B to IEC751. In this instrument, the element encapsulated in a silicone rubber patch with self-adhesive aluminium foil backing [LABFACILITY Ltd. 2016]. Sensor dimension is: length $40 \mathrm{~mm} \times$ width $13 \mathrm{~mm} \times$ height $5 \mathrm{~mm}$ respectively. The lead type is used for this is the Teflon ${ }^{\circledR}$ insulated. This instrument can measure $-50^{\circ} \mathrm{C}$ to $+150^{\circ} \mathrm{C}$ [LABFACILITY Ltd. 2016]. There are two 
platinum silicone patch sensors (RTF5) installed in the green blue roof and control roof to measure the surface temperature during different time scenarios. This is very efficient device to measure the surface temperature in an area.

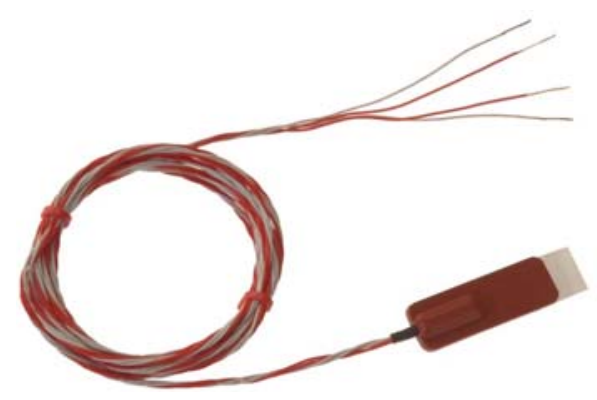

Fig. 3. Platinum silicone patch sensors (RTF5); source: LABFACILITY Ltd. [2016].

\section{RESULTS AND DISCUSSION}

\section{SURFACE TEMPRATURE MEASUREMENT}

Surface temperature was measured from the green blue roof and control roof at four different time periods. Green blue roof consisted of vegetation which grows on the soil media, which are very helpful for the evapotranspiration in an area. The vegetation/ plants in the green blue roof enhanced the evapotranspiration rate, which decreases the temperature in the urban areas. While on the other hand, control roof has no vegetation, and evapotranspiration is almost zero, so that the temperature of the control roof is higher as compared to the green blue roof. From the results, it is proved that green blue roof surface temperature in every case is less than the control roof which is very helpful to control urban heat island phenomena.

The Figure 4 represented the surface temperature measurement from the both roofs during the different time scenarios. From the results it is concluded that the surface temperature of the green blue roof during all the time scenarios is less than as compared to the control roof at the Cheong-un middle school building, Seoul, Korea. The average surface temperature reduction from the green blue roof was $4^{\circ} \mathrm{C}$ as compared to the control roof surface temperature.

The results of green blue roof agree with the results obtained from the other studies [ODLI et al. 2016; TANG et al. 2007; YIN, Li 2007]. For example, YIN and LI [2007] studied the green roof in Beijing, China to control the heat island phenomena. Results indicated the surface temperature reduction on average $2.4^{\circ} \mathrm{C}$ from green roof as compared to common roof. Vegetation/plants are responsible for evapotranspiration, so there is a need for more research to select the optimum vegetation for the green roof. There is
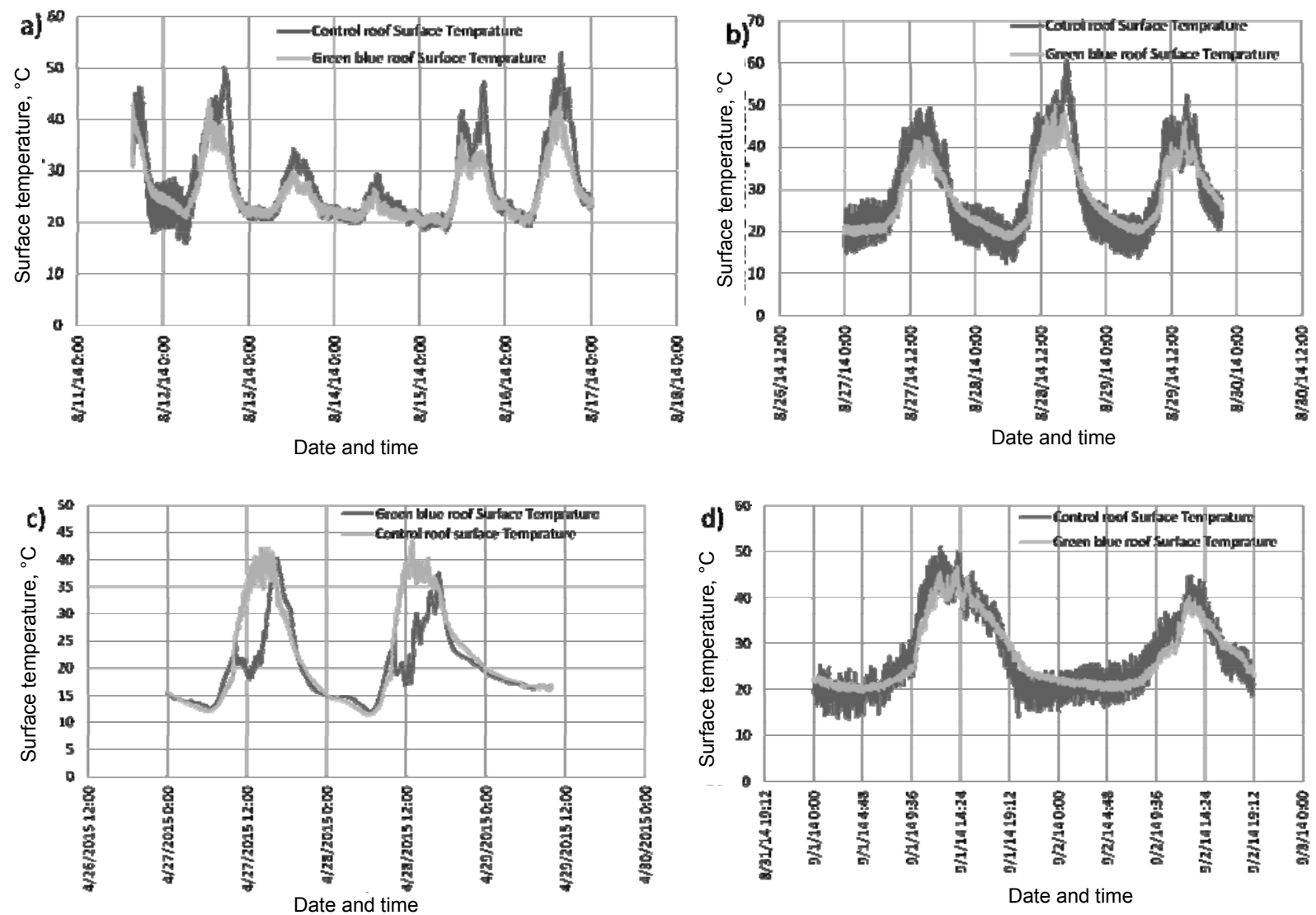

Fig. 4. Variation of surface temperature from green blue roof and control roof at different time interval where, a) 11 Aug. - 17 Aug. 2014; b) 27 Aug. - 30 Aug. 2014; c) 26 April - 26 April. 2015; d) 1 Sept - 2 Sept. 2014; source: own study 
also a need to select optimum soil depths to store excess rainwater that evaporates into the space and reduce the surface temperature in an area.

The storage layer depth in the green blue roof can be increased to store more water and it could enhance the storage capacity of rainwater in the green blue roof. In Seoul, Republic of Korea, $30 \mathrm{~mm} \cdot$ day $^{-1}$ precipitation is recommended for the rainwater harvesting. We could change the depth of the storage layer of the green blue roof according to the required amount of water needed for the watering to the vegetation of the green blue roof. We could manage the rainwater in green blue roof storage layer to avoid flash flooding and to irrigation to the vegetation/plants of the green blue roof. We can also store rainwater in a rain barrel and rain cistern for the watering to the green roof/green blue roof in urban areas. In this way, we can utilize the rainwater more efficiently and effectively and can get more benefits from this roof system. This roof type is very helpful to reduce heat waves and resilient to climate change in an area. The green blue roof is a very effective low impact development LID practice to cool the urban areas and it can make our cities safer, sustainable and resilient to climate change.

\section{CONCLUSIONS}

The urban heat island effect, as one of the consequences of urbanization, could affect the city environment and quality of life. The main source of the UHI is the urban structure such as roads and building etc., as they absorb the solar radiations which increase the temperature of an area. Increasing the green areas is the most effective and efficient strategy to mitigate the UHI.

This study shows that green blue roof surface temperature is less than as compared to the control roof. Results also showed that an average reduction in the surface temperature of the green blue roof was $5^{\circ} \mathrm{C}$ to $9^{\circ} \mathrm{C}$ as compared to control under the same conditions. Moreover, green blue roof is capable of decreasing the energy usage costs by decreasing the temperature of an urban area. Green roof and blue roof can be combined in such a way that the water from blue roof can be used for the irrigation to the green roof. Presently, there is also need to make the best combination of bioretention, green roof and green blue roof in such a way that multiple benefits with low economy could be achieved. There is also need to develop a more cost effective and efficient LID facility which has multiple benefits in urban areas. For this purpose the different LID practices could be combined in a suitable way that can give multiple benefits in an area.

\section{Acknowledgments}

This research was supported by a grant (15technology innovationC04) from Advanced Water Management Research Program funded by the Ministry of Land, Infrastructure and Transport of Korean government.

\section{REFERENCES}

Adinna E., Christian E.I., OKolie A.T. 2009. Assessment of urban heat island and possible adaptations in Enugu urban using landsat-ETM. Journal of Geography and Regional Planning. Vol. 2. Iss. 2 p. 30-36.

AKBARI H., KonOPACKI S. 2004. Energy effects of heatisland reduction strategies in Toronto, Canada. Energy. Vol. 29. Iss. 2 p. 191-210.

AKBARI H., KONOPACKI S. 2005. Calculating energy-saving potentials of heat-island reduction strategies. Energy Policy. Vol. 33. Iss. 6 p. 721-756.

Akbari H., Pomerantz M., Taha H. 2001. Cool surfaces and shade trees to reduce energy use and improve air quality in urban areas. Solar Energy. Vol. 70. Iss. 3 p. $295-310$.

ARABI R., SHAHIDAN M.F., KAMAl M.M., JAAFAR M.F.Z.B., RAKHSHANDEHROO M. 2015. Mitigating urban heat island through green roofs. Current World Environment. Vol. 10. Sp. iss. 1 p. 918-927.

FENG Y., WANG P., WU Z. 2013. Research on the ecological effects for different types of green roofs in Chongqing. Journal of South China Agricultural University. Vol. 7. Iss. 12 p. $17-28$.

GRIMMOND S. 2007. Urbanization and global environmental change: Local effects of urban warming. Geographical Journal. Vol. 173. Iss. 1 p. 83-88.

Hossain N., BAHAUDDIN K.M. 2013. Integrated water resource management for mega city: A case study of Dhaka city, Bangladesh. Journal of Water and Land Development. No. 19 p. 39-45.

LABFACILITY Ltd. 2016. Temperature and process technology, UK [online]. [Access 25.12.2016]. Available at: https://www.labfacility.com

Li D., Bou-Zeid E., Oppenheimer M. 2014. The effectiveness of cool and green roofs as urban heat island mitigation strategies. Environmental Research Letters. Vol. 9. No. 5055002 p. 1-16.

LuO Z. 2009. Research on the power savings effects and thermal property of light weighted green roof in Shenzhen. Chongqing. Chongqing University Press.

Niachou A., Papakonstantinou K., Santamouris M., Tsangrassoulis A., MihalaKaKou G. 2001. Analysis of the green roof thermal properties and investigation of its energy performance. Energy and Buildings. Vol. 33. Iss. 7 p. 719-729.

NURUZZAMAN MD. 2015. Urban heat island: Causes, effects and mitigation measures - A review. International Journal of Environmental Monitoring and Analysis. Vol. 3. Iss. 2 p. 67-73.

OdLi Z.S.M., ZAKARYA I.A., MOHD F.N., IZHAR T.N.T., IBRAHIM N.M., MOHAMAD N. 2016. Green roof technology-mitigate urban heat island (UHI) effect. MATEC Web of Conferences. Vol. 78 art. 01100 p. 1-7.

PENG L.L., JIM C.Y. 2013. Green-roof effects on neighborhood microclimate and human thermal sensation. Energies. Vol. 6. Iss. 2 p. 598-618.

Saiz S., Kennedy C., Brass B., Pressnail K. 2016. Comparative life cycle assessment of standard and green roof. Environmental Science and Technology. Vol. 40. Iss. 13 p. 4312-4316.

SANTAMOURIS M. 2014. Cooling the cities - A review of reflective and green roof mitigation technologies to fight heat island and improve comfort in urban environments. Solar Energy. Vol. 103 p. 682-703.

SANTOS F. 2013. Trees - the natural air conditioners [online]. Scientific Scribbles. The University of Mel- 
bourne. [Assessment 25.12.2016]. Available at: https:// blogs.unimelb.edu.au/sciencecommunication/2013/08/2 3/trees-the-natural-air-conditioners/

Shafique M., LeE D., Kim R. 2016. A field study to evaluate runoff quantity from blue roof and green blue roof in an urban area. International Journal of Control and $\mathrm{Au}-$ tomation. Vol. 9. Iss. 8 p. 59-68.

Sharma A., Conry P., Fernando H.J.S., Hamlet A.F., Hellmann J.J., CHEN F. 2016. Green and cool roofs to mitigate urban heat island effects in the Chicago metropolitan area: Evaluation with a regional climate model. Environmental Research Letters. Vol. 11. Iss. 6 art. 064004 p. 1-15.

SHISHEGAR N. 2014. The impact of green areas on mitigating urban heat island effect: A review. International Journal of Environmental Sustainability. Vol. 9. Iss. 1 p. 119-130.

Stovin V., Vesuviano G., Kasmin H. 2012. The hydrological performance of a green roof test bed under UK cli- matic conditions. Journal of Hydrology. Vol. 414-415 p. $148-161$.

SuRMA M. 2015. Sustainable urban development through an application of green infrastructure in district scale A case study of Wrocław (Poland). Journal of Water and Land Development. No. 25 p. 3-12.

TAKebayashi H., Moriyama M. 2007. Surface heat budget on green roof and high reflection roof for mitigation of urban heat island. Building and Environment. Vol. 42. Iss. 8 p. 2971-2979.

TANG M., YANG Z., LI L. 2007. Thermal characteristic of natural grass land style green roof. HW Ventilation on Chinese HVAC Journal. Vol. 37. No. 3 p. 1-4.

XiAo M., Lin Y., HAN J., ZHANG G. 2014. A review of green roof research and development in China. Renewable and Sustainable Energy Reviews. Vol. 40 p. 633-648.

YIN L., Li S. 2007. Temperature character of roof greening on low energy demo building of Tsinghua University. Scientia Silvae Sinica. Vol. 43. Iss. 8 p. 143-147.

\section{Muhammad SHAFIQUE, Reeho KIM}

\section{Zastosowanie zielono-niebieskich dachów lagodzących zjawiska „wysp ciepła” i lagodzących skutki zmian klimatu na terenach miejskich: przykład z Seulu, Korea}

\section{STRESZCZENIE}

Zielono-niebieskie dachy mają zdolność obniżania temperatury powierzchni budynku na terenach miejskich. Jest to innowacyjna technologia wdrażana w ramach ,zielonej infrastruktury”, która ma łagodzić zjawisko „miejskiej wyspy ciepła”. Stanowi zmodyfikowaną wersję zielonego dachu, który jest w stanie zatrzymywać wody opadowe w roślinności i warstwie gleby, zwiększając ewapotranspirację, przez co obniża temperaturę danego obszaru. W celach badawczych zainstalowano zielono-niebieski dach na budynku szkoły średniej Cheong-un w Seulu, w Korei. Analizowano i porównywano temperatury dachu kontrolnego i dachu zielono-niebieskiego. Uzyskane wyniki wskazują, że temperaturę powierzchni zielono-niebieskiego dachu była znacznie niższa niż temperatura kontrolnego dachu w tych samych warunkach pogodowych. Różnice temperatur wynosiły od 5 do $9^{\circ} \mathrm{C}$.

Słowa kluczowe: miejska wyspa ciepła, obniżenie temperatury, obszary miejskie, zielona infrastruktura, zielono-niebieski dach 